\title{
THE USAGE OF MOBILE APPS IN AGRICULTURE
}

\author{
P. TAMIL SELVI ${ }^{1} \&$ Dr. P. BALASUBRAMANIAM ${ }^{2}$ \\ ${ }^{I}$ Scholar, Department of Agricultural Extension and Rural Sociology Tamil Nadu Agricultural University, \\ Coimbatore, Tamil Nadu, India \\ ${ }^{2}$ Professor and Head, Department of Agricultural Extension and Rural Sociology Tamil Nadu Agricultural University,
}

Coimbatore, Tamil Nadu, India

\begin{abstract}
In India farmers have poor market infrastructure, inadequate marketing experience, and agricultural inputs. These farmers need to access information about new technologies before they can consider adopting them and thus look up to research and extension agents as sources of new technologies. Access to appropriate information and knowledge is an overriding factor for successful agricultural production and thus rural development. However, the traditional approach of providing agricultural information through extension services is overstretched and under-resourced. Accurate and timely market information, particularly of perishable items, can significantly reduce transaction and travel costs. Nowadays, the mobile apps have generated an opportunity for the farmers especially to get the information about marketing and weather. This important technology, they directly keep in touch with market personals and offer their produce with reasonable prices. The use of mobile apps also keep them aware for weather forecast for agriculture input application like fertilizer and pesticides which might be affected by unforeseen seen disasters as communicated by meteorological department. Based on above facts a study on the usage of mobile apps in agriculture was conducted. Two blocks namely Thogaimalai and Kulithalai were selected randomly in Karur District. The researcher found that farmers got more awareness about mobile apps. Through mobile apps they were getting agricultural and allied information on time. Many apps are being utilized for different kind of functionality regarding the farming activities like cropping information, pesticides, fertilizer, seed, selling of crop, irrigation information, estimation of crop production, weather information and information regarding the best practices of farming.

KEYWORDS: Mobile Communication, Agri Apps, Mobile Apps, Types of Mobile Apps, Usage of Agri Apps \& Benefits of Mobile Apps
\end{abstract}

Received: May 27, 2019; Accepted: Jun 17, 2019; Published: Jul 04, 2019; Paper Id.: IJASRAUG201928

\section{INTRODUCTION}

Mobile communications technology has become the world's most common way of transmitting voice, data, and services, and no technology has ever spread faster. At the end of 2011 there were almost 6 billion cellular telephone subscriptions worldwide, and the number is expected to reach 8 million by the end 2016. Mobile phone usage in third world countries is playing a vital role for the enhancement of farmers business towards agriculture. Recently, communication through mobile phones is considered very important in enhancing farmers' access to better understand the agricultural market situation. Farming communities appreciate a mobile phone as easy, fast and convenient way to communicate and get prompt answers of respective problems. Nowadays, the mobile phone has generated an opportunity for the farmers especially to get the information about marketing and weather. Through this important technology, they directly keep in touch with market personals and offer their produce with 
reasonable prices. The use of mobile phone, also keep them aware of the weather forecast for agriculture input applications like fertilizer and pesticides which might be affected by unforeseen seen disasters as communicated by meteorological department.

Agri App is a revolutionary Android based mobile application. It provides complete information on Crop Production, Crop Protection and all relevant agriculture allied services on your Smartphone. Agri App is also an online market place bringing farmers, agri inputs, and retail \& fulfillment services on a common digital platform. Increasing agricultural productivity, profitability, and sustainability in the developing world depends on the ability of rural populations to adopt changes and innovations in their use of technologies, management systems, organizational arrangements, institutions and environmental resources. M-apps also play an important role in expanding timely access to rural extension and advisory services to meet the immediate needs of farmers and other rural residents as they change their production and livelihood systems (McNamara, Kerry S. (2009)). Different types of mobile apps are given below:

\section{Kisan Suvidha}

Kisan Suvidha is an omnibus mobile app developed to help farmers by providing relevant information to them quickly. With the click of a button, they can get the information on weather of current day and next 5 days, dealers, market prices, agro advisories, plant protection, IPM Practices etc. Unique features like extreme weather alerts and market prices of commodity in nearest area and the maximum price in state as well as India have been added to empower farmers in the best possible manner.

\section{Pusa Krishi}

ZTM \& BPD Unit; ICAR-IARI, New Delhi is leading 14 ICAR institutes of North Zone-I. The unit strives to be a strong link between the research community and the outside world. It promotes Agribusiness Ventures through technology development and commercialization for everyone from a corporate to an individual farmer. We have a variety of technologies / products for commercialization. Some technologies may be market ready, however some may require validation and some may require up scaling. We license our technologies to both private and public sectors.

\section{Agri Market}

The Agri Market mobile app can be used to get the market price of the crops in the markets within $50 \mathrm{~km}$ of the device's location. This app automatically captures the location of the person using mobile GPS and fetches the market price of crops in those markets which falls within the range of $50 \mathrm{~km}$. There is another option to get price of any market and any crop in case person does not want to use GPS location.

\section{Pashu Poshan}

NDDB has developed android based software that can be used on phones as well as tablets. With the help of this software balanced ration is formulated while optimizing the cost considering animal profile, i. e. cattle or buffalo, age, milk production, milk fat, and feeding regime etc. and milk producers are advised to adjust the quantity of locally available feed ingredients offered to their animals along with mineral mixture. 


\section{Digital Mandi India}

This App helps in checking the latest Indian agricultural commodities Mandi prices from different states and districts. Easy to use and intuitive, the app enables farmers, traders and all others to know the updated Mandi price from anywhere. Its main features are: Browse through various commodity categories, Browse prices in different states, Simplified flow to reach the selected commodity's mandi price, Copy the mandi price of a commodity and Sync data from the Indian government portal Agmarknet.nic.in.

\section{RESEARCH METHODOLOGY}

The study was conducted in Karur district of Tamil Nadu involving 150 farmers. Out of the eight blocks of Karur district, two blocks were selected at random. From each block, five villages were selected by using simple random sampling.75 farmers were selected randomly in each block. A well- structured interview schedule was used for data collection from the respondents.

\section{FINDINGS AND DISCUSSIONS}

The findings of the study are being presented hereunder.

Age

Age has been considered as a factor which might influence the farmer to perform his/her needs. Therefore, age has been included in this study. The findings on age distribution of respondents are given in Table 1.

Table 1: Distribution of Respondents according to their Age

\begin{tabular}{|c|c|c|c|c|}
\hline \multirow{2}{*}{ Category } & \multicolumn{2}{c}{ Rain Fed } & \multicolumn{2}{c|}{ Irrigated } \\
\cline { 2 - 5 } & Number & Per cent & Number & Per cent \\
\hline Young - up to 35 years & 14 & 19 & 13 & 17 \\
\hline Middle - above 36 - upto 50 years & 36 & 48 & 11 & 15 \\
\hline Old - more than 51 years & 25 & 33 & 51 & 68 \\
\hline Total & $\mathbf{7 5}$ & $\mathbf{1 0 0}$ & $\mathbf{7 5}$ & $\mathbf{1 0 0}$ \\
\hline
\end{tabular}

Table 1 reveals that majority of the irrigated farmers were old aged (68.00 per cent) followed by young aged (17.00 per cent) and the rest of them (15.00 per cent) were middle aged. Out of 150 respondents 27 numbers of young aged farmers, 47 numbers of middle aged farmers and 76 numbers of old aged farmers were used agri apps in their mobile.

\section{Educational Status}

Literacy level of the farmers is one of the important factors, which influences their adoption level of mobile apps. The data on educational level of the farmers were collected and presented in Table 2.

Table 2: Distribution of Respondents according to their Educational Status

\begin{tabular}{|c|c|c|c|c|}
\hline \multirow{2}{*}{ Category } & \multicolumn{2}{|c|}{ Rain Fed } & \multicolumn{2}{c|}{ Irrigated } \\
\cline { 2 - 5 } & Number & Per cent & Number & Per cent \\
\hline School level & 62 & 83 & 58 & 77 \\
\hline College level & 13 & 17 & 17 & 23 \\
\hline Total & $\mathbf{7 5}$ & $\mathbf{1 0 0}$ & $\mathbf{7 5}$ & $\mathbf{1 0 0}$ \\
\hline
\end{tabular}

Table 2 reveals that the analysis of educational status of the rain fed farmers revealed that majority ( 83.00 per cent) of them were educated up to school level, followed by College level (17.00 per cent). Out of 150 respondents 120 
farmers were completed school level education and 30 farmers were completed college level education. Because old aged farmers were having more interest in agriculture.

\section{Farm Size}

It is the area of land possessed by an individual. The categorization was as follows:

Table 3: Distribution of Respondents according to their Farm Size

\begin{tabular}{|l|c|c|c|c|}
\hline \multicolumn{1}{|c|}{ Category } & \multicolumn{2}{|c}{ Rain Fed } & \multicolumn{2}{c|}{ Irrigated } \\
\cline { 2 - 5 } \multicolumn{1}{|c|}{} & Number & Per cent & Number & Per cent \\
\hline $0-2.5$ acres & 7 & 9 & 1 & 1 \\
\hline Up to 5 acres & 29 & 39 & 24 & 32 \\
\hline More than 5 acres & 39 & 52 & 50 & 67 \\
\hline Total & $\mathbf{7 5}$ & $\mathbf{1 0 0}$ & $\mathbf{7 5}$ & $\mathbf{1 0 0}$ \\
\hline
\end{tabular}

It is observed from the table, 39 farmers in rain fed area and 50 farmers in irrigated area were having more than 5 acres land. Compared to small farmers, the big farmers were needed more information about various crop cultivation techniques and weather information.

\section{Occupation}

It was considered as parental professing of the respondents. The occupation was categorized into three groups and scoring pattern was adopted as follows:

Table 4: Distribution of Respondents according to their Occupation

\begin{tabular}{|l|c|c|c|c|}
\hline \multirow{2}{*}{ Category } & \multicolumn{2}{|c}{ Rain Fed } & \multicolumn{2}{c|}{ Irrigated } \\
\cline { 2 - 5 } \multicolumn{1}{|c|}{} & Number & Per cent & Number & Per cent \\
\hline Farming alone & 51 & 68 & 62 & 82.7 \\
\hline Farming + Business & 24 & 32 & 13 & 17.3 \\
\hline Farming + Govt. job & 0 & 0 & 0 & 0 \\
\hline Total & $\mathbf{7 5}$ & $\mathbf{1 0 0}$ & $\mathbf{7 5}$ & $\mathbf{1 0 0}$ \\
\hline
\end{tabular}

Table 4 reveals that the Majority ( 82.7 per cent) of the irrigated farmers were farming alone, followed by Farming and business (17.3 per cent). In irrigated area the major crops were banana and sugarcane. So, farmers were fully involved in crop cultivation aspects throughout the year compared to rain fed farmers.

\section{Annual Income}

It referred to the total amount an individual earned through crop production without considering the cost of cultivation. This was calculating by converting the total crop production during the year of survey with existing prices of different grains and summed up to set the total annual income in to rupees and on the basis of range of data categories were formed as:

Table 5: Distribution of Respondents according to their Annual Income $(\mathbf{n}=\mathbf{1 5 0})$

\begin{tabular}{|l|c|c|c|c|}
\hline \multirow{2}{*}{ Category } & \multicolumn{2}{c|}{ Rain Fed } & \multicolumn{2}{c|}{ Irrigated } \\
\cline { 2 - 5 } & Number & Per cent & Number & Per cent \\
\hline $\begin{array}{l}\text { Low } \\
\text { (up to Rs. 50000) }\end{array}$ & 47 & 62.7 & 26 & 34.7 \\
\hline $\begin{array}{l}\text { Medium } \\
\text { (Rs. 50000 to 100000) }\end{array}$ & 18 & 24 & 35 & 46.7 \\
\hline
\end{tabular}




\begin{tabular}{|l|c|c|c|c|}
\hline \multicolumn{5}{|c|}{ Table 5: Contd., } \\
\hline $\begin{array}{l}\text { High } \\
\text { (above Rs. 100000) }\end{array}$ & 10 & 13.3 & 14 & 18.6 \\
\hline \multicolumn{1}{|c|}{ Total } & $\mathbf{7 5}$ & $\mathbf{1 0 0}$ & $\mathbf{7 5}$ & $\mathbf{1 0 0}$ \\
\hline
\end{tabular}

The above table shows that the majority (46.7 per cent) of the irrigated farmers were got medium income, Followed by (18.6 per cent) high income. Because irrigated area farmers were having more irrigation facility compared to rain fed farmers. So, they cultivated cash crops like banana and sugarcane.

\section{Social Participation}

Participation in formal and non-formal organizations like village panchayat, co-operative society, farmer's commodity groups and farmers clubs provides access for more interactions with various sections of people. The conscious participation and deliberation in meetings and trainings in these organizations would help to improve the adoption level of mobile apps. The findings on social participation of respondents are given in Table 6.

Table 6: Distribution of Respondents according to their Social Participation

\begin{tabular}{|c|l|c|c|c|c|}
\hline \multirow{2}{*}{ S. No } & \multirow{2}{*}{ Name of Organization } & \multicolumn{2}{|c|}{ Rain Fed (No. s) } & \multicolumn{2}{c|}{ Irrigated (No. s) } \\
\cline { 3 - 6 } & & President & Member & President & Member \\
\hline 1 & Village Panchayat & 0 & 8 & 0 & 29 \\
\hline 2 & Cooperative society & 0 & 42 & 0 & 20 \\
\hline 3 & Farmers commodity groups & 2 & 9 & 2 & 10 \\
\hline 4 & Farmers clubs & 2 & 12 & 5 & 9 \\
\hline
\end{tabular}

The above table shows that the majority (42 numbers) of the rain fed farmers were having more social participation in Cooperative society, followed by (12 numbers) in farmers club. Rain fed area farmers were having majority of social participation compared to irrigated area farmers. Because they need support from Cooperative society for getting crop loans and farmers groups for getting government subsidy schemes. In irrigated area they need support from village Panchayat for getting information about water release in canals. Then only they will start their agricultural operations on time. Due to this reason, they will have less interest in other organization participation.

\section{Mass Media Exposure}

Mass media plays a vital role in gaining knowledge about advanced crop production technologies. Day to day information is communicated through newspapers, radio and television. At present one cannot think about development without media. The findings on mass media exposure of respondents are given in Table 7.

Table 7: Distribution of Respondents according to their Mass Media Exposure

\begin{tabular}{|c|c|c|c|c|c|c|c|c|c|c|c|c|c|}
\hline \multirow{4}{*}{ S. No } & \multirow{4}{*}{ Source } & \multicolumn{12}{|c|}{ Frequency } \\
\hline & & \multicolumn{4}{|c|}{ Regularly } & \multicolumn{4}{|c|}{ Occasionally } & \multicolumn{4}{|c|}{ Never } \\
\hline & & \multicolumn{2}{|c|}{ Rain Fed } & \multicolumn{2}{|c|}{ Irrigated } & \multicolumn{2}{|c|}{ Rain Fed } & \multicolumn{2}{|c|}{ Irrigated } & \multicolumn{2}{|c|}{ Rain Fed } & \multicolumn{2}{|c|}{ Irrigated } \\
\hline & & No. & Per cent & No. & Per cent & No. & Per cent & No. & Per cent & No. & Per cent & No. & Per cent \\
\hline 1 & Newspaper & 75 & 100 & 75 & 100 & 0 & 0 & 0 & 0 & 0 & 0 & 0 & 0 \\
\hline 2 & Journals & 0 & 0 & 0 & 0 & 35 & 46.7 & 52 & 69.3 & 40 & 53.3 & 23 & 30.7 \\
\hline 3 & Radio & 12 & 16 & 4 & 5.3 & 21 & 28 & 14 & 18.7 & 42 & 56 & 57 & 76 \\
\hline 4 & Television & 44 & 58.7 & 38 & 50.7 & 31 & 41.3 & 37 & 49.3 & 0 & 0 & 0 & 0 \\
\hline 5 & Mobile apps & 28 & 37.3 & 21 & 28 & 19 & 25.3 & 18 & 24 & 28 & 19 & 36 & 48 \\
\hline
\end{tabular}

The majority (100 per cent) of the farmers in both rain fed and irrigated area received Agricultural related information regularly from newspapers. Compared to irrigated farmers, rain fed farmers were having regular (58.7 per 
cent) Television exposure, followed by (37.3 per cent) Mobile apps exposure. Because, Rain fed farmers needs weather related information and Govt. Subsidy schemes regularly compared to irrigated farmers.

\section{MOBILE APPS - ADOPTION LEVEL}

Values in Table 8 reveal the comparison of adoption level of mobile apps in both rain fed and irrigated area farmers. In rain fed area, $63 \%$ of farmers adopted the agri apps in their mobile phone. In irrigated area only $52 \%$ of farmers were used agri apps.

Table 8: Distribution of Respondents according to their Mobile Apps - Adoption Level

\begin{tabular}{|c|c|c|c|c|}
\hline \multirow{2}{*}{ Category } & \multicolumn{2}{|c|}{ Rain Fed } & \multicolumn{2}{c|}{ Irrigated } \\
\cline { 2 - 5 } & Number & Per Cent & Number & Per Cent \\
\hline Adopted farmers & 47 & 63 & 39 & 52 \\
\hline Non adopted farmers & 28 & 37 & 36 & 48 \\
\hline Total & $\mathbf{7 5}$ & $\mathbf{1 0 0}$ & $\mathbf{7 5}$ & $\mathbf{1 0 0}$ \\
\hline
\end{tabular}

Compared to irrigated farmers, rain fed farmers wants more information about irrigation management practices, farm ponds and drought mitigation techniques. So, they have more interested in installing mobile apps in their phone.

\section{USAGE OF DIFFERENT TYPES OF MOBILE APPS AMONG FARMERS}

At the time of Agricultural meeting and training programme State agriculture department officials and Krishi Vigyan Kendra scientists were explained the uses of Kissan suvidha app. They downloaded the app in farmers mobile also.

Table 9: Distribution of Respondents according to their Types of Mobile Apps Usage

\begin{tabular}{|l|c|c|c|c|}
\hline \multirow{2}{*}{ Category } & \multicolumn{2}{|c|}{ Rain Fed } & \multicolumn{2}{c|}{ Irrigated } \\
\cline { 2 - 5 } & Number & Per cent & Number & Per cent \\
\hline Kissan Suvidha & 36 & 48 & 29 & 38.7 \\
\hline IFFCO Kisan & 8 & 10.7 & 7 & 9.3 \\
\hline RML & 3 & 4 & 3 & 4 \\
\hline
\end{tabular}

The table 9 shows that the majority (48 per cent) of the rain fed farmers were using the Kissan suvidha app, followed by (10.7 per cent) IFFCO Kisan app. Kissan suvidha app contains information like weather of current day and next 5 days, dealers, market prices, agro advisories, plant protection and IPM Practices etc. in Tamil language. So, the farmers were having more interest to use this app. compared to other apps.

\section{BENEFITS OF MOBILE APPS IN AGRICULTURE}

Table 10: Distribution of Respondents according to their Benefits Getting through Mobile Apps

\begin{tabular}{|l|c|c|c|c|}
\hline \multicolumn{1}{|c|}{ Category } & \multicolumn{2}{c|}{ Rain Fed } & \multicolumn{2}{c|}{ Irrigated } \\
\cline { 2 - 5 } & Number & Per cent & Number & Per cent \\
\hline Better understand agricultural market situation & 49 & 65.3 & 63 & 84 \\
\hline Easy, fast and convenient way to communicate & 64 & 85.3 & 71 & 94.6 \\
\hline To get the information about weather. & 69 & 92 & 42 & 56 \\
\hline To sell their produce with reasonable prices. & 18 & 24 & 34 & 45.3 \\
\hline Weather forecast & 36 & 48 & 59 & 78.6 \\
\hline
\end{tabular}

Table no. 10 shows that the Majority (92 per cent) of the irrigated farmers were more interested in receiving weather related information through SMS or Voice calls. Based on the weather information they planned their sowing time, 
fertilizers and pesticides application work. Farmers think that the mobile apps were easy, fast and convenient way to communicate their crop protection related problems and get the solutions from scientists. Beyond the crop cultivation aspects farmers were need market price for their commodities. In comparing rain fed area, the irrigated area farmers 84 percent need market related information

\section{PROBLEMS FACED BY FARMERS}

Table 11: Distribution of Respondents according to their Problems

\begin{tabular}{|c|c|c|c|c|}
\multicolumn{4}{|c}{ Rain Fed } & \multicolumn{2}{c|}{ Irrigated } \\
\hline \multirow{2}{*}{ Category } & \multicolumn{2}{|c|}{ Rain } \\
\cline { 2 - 5 } & Number & Per cent & Number & Per cent \\
\hline Costly & 67 & 89 & 56 & 75 \\
\hline Skill is required & 42 & 56 & 46 & 61 \\
\hline No internet facility & 51 & 68 & 43 & 57 \\
\hline Language problem & 49 & 65 & 53 & 71 \\
\hline Network problem & 33 & 44 & 24 & 32 \\
\hline
\end{tabular}

Majority of the farmers ( 89 per cent) were told that the android phone cost is very high. It's not an affordable price for farmers. Because they were spend more money for crop cultivation aspects. Farmers were also facing language problem due to illiteracy. So, they are unable to read and write their problems and solutions given by scientists. They are also facing internet problem in their villages.

\section{CONCLUSIONS}

The researcher found that farmers got more awareness about mobile apps. Through mobile apps they were getting agricultural and allied information on timely. This research also finds that the following problems are associated with the use of mobile apps - poor network services, high charges, Language problem and Skill is required. Many apps are being utilized for different kind of functionality regarding the farming activities like cropping information, pesticides, fertilizer, seed, selling of crop, irrigation information, estimation of crop production, weather information and information regarding the best practices of farming. This study recommends that all listed benefits are bundle into the one single app and in the native language of the farmer, and then it is easy to utilize it.

\section{REFERENCES}

1. Agüero, Aileen (2009), 'Education, mobile phone use and production decisions: a rural case study in Peru', "Mobile 2.0: Beyond Voice?" Pre-conference workshop at the International Communication Association (ICA).

2. Cantor, Eric (2009), 'Reaching the Hardest to Reach: Mobile apps for low-income communities', Mobile Web Africa Conference.

3. Bairwa, S. L., Kumari, M. \& Meena, L. K. (2015). Developing mobile based agri retailing (MBAR) model for high value agricultural and livestock products. International Journal of Agricultural Science and Research (IJASR), 5 (6): 125, 130.

4. Jagun, Abi, Richard Heeks, and Jason Whalley (2008), 'The Impact of Mobile Telephony on Developing Country Micro-Enterprise: A Nigerian Case Study', Information Technologies and International Development, 4 (4), 47-65.

5. McNamara, Kerry S. (2009), 'Mobile Applications in Agriculture and Rural Development_-Framing the Topic, and Learning from Experience', World Bank Workshop on Mobile Innovations for Social and Economic Transformation.

6. Sarkar, M., Sreelakshmi, K. \& Mithun, T. P. (2014). Multiband miniaturised fractal antenna for mobile communications. International Journal of Research in Engineering \& Technology, 2(4), 143-150. 
7. Mittal, Surabhi, Sanjay Gandhi and Gaurav Tripathi (2010), 'Socio-Economic Impact of Mobile Phones on Indian Agriculture', Working Paper, 24653.

8. Pande, Arun, Bhushan G. Jagyasi, and Ravidutta Choudhuri (2009), 'Late Blight Forecast Using Mobile Phone Based Agro Advisory System', Third International Conference, PReMI 2009, Pattern Recognition and Machine Intelligence 609-14. 